\title{
PERAN TEMAN SEBAYA TERHADAP PERILAKU SEKSUAL PRANIKAH PADA REMAJA SMA DI KOTA TEGAL
}

Nadia Ade Pratiwi*, Retna Siwi Padmawati**, Budi Wahyuni**

*Mahasiswa IImu Kesehatan Masyarakat Universitas Gadjah Mada **IImu Kesehatan Masyarakat Universitas Gadjah Mada

\section{LATAR BELAKANG}

Kasus mengenai perilaku seksual pada remaja dari waktu ke waktu semakin mengkhawatirkan karena perilaku seksual remaja sekarang ini sudah melebihi batas terutama pada masa remaja akhir.

Permasalahan remaja yang berkaitan engan kesehatan reproduksi sering kali erakar dari kurangnya informasi dan pemahaman serta kesadaran untuk mencapai sehat secara reproduksi. Akses untuk mendapatkan informasi bagi remaja banyak yang tertutup (1).

Kota Tegal sebagai daerah persimpangan yang merupakan daerah berpotensi untuk terjadinya penyebaran IMS (Infeksi Menular Seksual) dan HIVIAIDS Sebagian besar pekerjaan orang tua siswa adalah pedagang warteg di Jakarta dan anak-anak pemilik warteg ini dibesarkan jauh dari orangtua sehingga pergaulan remaja mereka kurang mendapat perhatian sehingga dapat timbul perilaku nakal seperti perilaku seksual pranikah.

\section{TUJUAN}

Tujuan penelitian ini untuk mengetahui hubungan peran teman sebaya dan akses media pornografi terhadap perilaku seksual pranikah pada remaja SMA di Kota Tegal.

\section{METODE}

Penelitian ini menggunakan rencangan studi cross sectional. Penelitian ini dilaksanakan di SMA Kota Tegal dan lebih menekankan pada remaja yang sedang berada di kelas XI SMA atau berusia antara 15 sampai 19 tahun. Besa sampel dalam penelitian ini sebanyak 254 responden. Pengumpulan data dengan mengunakan kuesioner. Analisis bivariat menggunakan Chi square dengan tingkat kemaknaan $p<0.05$.

\section{HASIL}

Sebagian besar responden adalah perempuan. Responden lebih banyak yang tinggal bersama orang tua. Sebagian besar pendidikan orang tua responden yaitu tamat SMA dan sebagian besar pekerjaan orang tua responden yaitu berwirausaha

Grafik 1. Perilaku Seksual Pranikah

Perilaku Seksual Pranikah

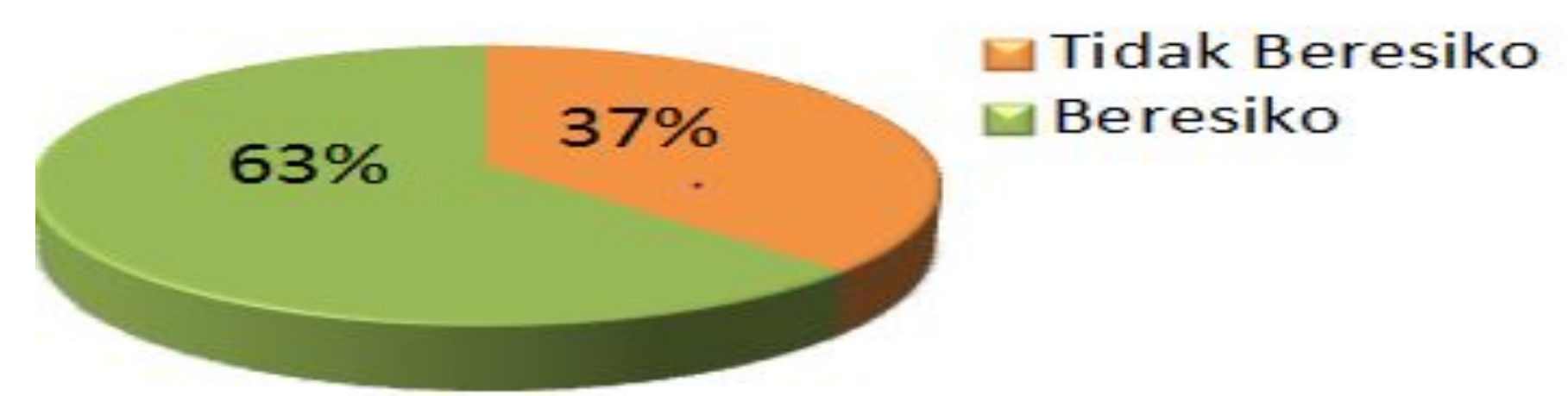

Grafik 1 menunjukkan perilaku seksua pranikah yang beresiko sebesar $62,60 \%$. Sebagian besar $(62,60 \%)$ teman sebaya mendukung untuk melakukan seksual pranika dan sebagian besar $(54,33 \%)$ remaja banyak yang mengakses media pornografi.
Tabel 1. Analisis Bivariat peran teman sebaya dan akses media pornogra

\begin{tabular}{lrrrr|} 
Variabel & $\begin{array}{c}\text { Beresik0 } \\
\mathbf{n}(\%)\end{array}$ & $\begin{array}{c}\text { Tidak beresiko } \\
\mathbf{n}(\%)\end{array}$ & $\begin{array}{c}\mathrm{P} \\
\text { value }\end{array}$ & OR $(95 \% \mathrm{CI})$ \\
\hline $\begin{array}{l}\text { Peran Teman Sebaya } \\
\text { Tidak mendukung }\end{array}$ & $50(52,63)$ & $45(47,37)$ & 0,35 & $1,75(1,0408-2,942)$ \\
Mendukung & $105(66,04)$ & $54(33,96)$ & & \\
Akses dan kontak media porno & & & \\
Rendah & $61(52,59)$ & $55(47,41)$ & 0,012 & $1,926(1,155-3,210)$ \\
Tinggi & $94(68,12)$ & $44(31,88)$ & & \\
\hline
\end{tabular}

Tabel 1 menunjukkan remaja yang melakukan perilaku seksual pranikah beresiko dan didukung oleh teman sebaya lebih besa 1,75 kali dibanding dengan yang tidak mendukung. Remaja yang melakukan perilaku seksual pranikah beresiko dengan akses dan kontak media pornografi lebih besar 1,92 kali dibanding dengan akses dan kontak media pornografi yang rendah.

\section{PEMBAHASAN}

Semakin besar dukungan dari teman sebaya maka semakin memiliki kecenderungan untuk berperilaku seksual pranikah beresiko pada remaja, karena teman sebaya juga merupakan salah satu sumber informasi tentang seks yang cukup signifikan dalam membentuk pengetahuan, sikap dan perilaku seksual remaja. Namun, informasi teman sebaya dapat menimbulkan dampak yang negatif (2).
Selain peran teman sebaya, remaja yang mengakses dan kontak dengan media pornografi memiliki kecenderungan untuk berperilaku seksual ranikah beresiko, hal tersebut dikarenakan tayangan media baik media cetak maupun media elektronik memberi kontribusi yang signifikan terhadap munculnya kematangan seksual sebelum waktunya. Remaja yang sering mengeksploitasi seks di video klip, majalah dan televisi ternyata mendorong remaja melakukan aktivitas seks bebas (3).

\section{KESIMPULAN}

Peran teman sebaya dan akses media pornograf merupakan faktor yang berhubungan dengan perilaku seksual pranikah pada remaja. Sebaiknya remaja mengikuti kegiatan positif seperti membentu kelompok belajar untuk membahas mengenai kesehatan reproduksi dengan didampingi oleh guru pembimbing.

\section{PUSTAKA}

1. Mutiarawati (2013) Pengaruh Akses Informasi Kesehatan Reproduksi Remaja terhadap Praktik Kesehatan Reproduksi di SMA N 1 Pangkah Kabupaten Tegal. Jurnal Kebidanan.

2. Suparmi \& Isfandari, S. (2016) Peran Teman Sebaya terhadap Perilaku Seksual Pranikah pada Remaja Laki-laki dan Perempuan di Indonesia Buletin Penelitian Kesehatan, Vol. 44 (2) 139-146. 3. Yee, K. A., Cain, K. L., Carrillo, S. \& Lundgren, R. I. (2014) Teen Talking About Sexual Health: Girl-Directed Tools to Trigger Partne Communication. International Journal of Humanities and Social Science, Vol. 1 (18). 